\begin{tabular}{|l|l|}
\hline Postprint & 1.0 \\
Version & \\
\hline Journal website & \\
\hline Pubmed link & \\
\hline DOI & \\
\hline
\end{tabular}

This is a NIVEL certified Post Print, more info at http://www.nivel.eu

\title{
Hoe herkennen huisartsen behoefte aan palliatieve zorg?
}

\section{Door Susanne Claessen, AnNeKe Francke, Yvonne Engels en Luc Deliens}

Drs. Susanne Claessen is arts-onderzoeker bij het VU medisch centrum/EMGO Instituut, afdeling Sociale Geneeskunde.

Prof. dr. Anneke Francke is programmaleider Verpleging en Verzorging bij het NIVEL en bijzonder hoogleraar bij het VU medisch centrum/EMGO Instituut, afdeling Sociale Geneeskunde.

Dr. Yvonne Engels is universitair docent bij het UMC St. Radboud, afdeling Anesthesiologie, Pijn en Palliatieve Zorg.

Prof. dr. Luc Deliens is bijzonder hoogleraar Publieke Gezondheidszorg en Palliatieve Zorg bij het VU medisch centrum/EMGO Instituut, afdeling Sociale Geneeskunde.

Huisartsen gebruiken de term palliatieve zorg niet als genezing nog een optie is of als de patiënt nog weinig zorg nodig heeft.

Huisartsen herkennen een behoefte aan palliatieve zorg vaak op basis van een combinatie van signalen van de patiënt zelf, familie of andere professionals. In dit artikel geven de auteurs de belangrijkste conclusies uit interviews met 20 Nederlandse huisartsen.

\section{HET ONDERZOEK - WAAROM EN HOE}

In 2003 introduceerden Joanne Lynn en David Adamson een 'model' van palliatieve zorg waarin de palliatieve fase gezien wordt als een zorgcontinuüm met daarin een geleidelijke overgang van een accent op curatieve zorg naar palliatieve zorg. Echter, uit eerder onderzoek in België en Nederland blijkt dat de overgang naar palliatie vaak laat optreedt in het ziektetraject. ${ }^{1,2}$ Dit zou kunnen komen doordat huisartsen een behoefte aan palliatieve zorg van patiënten soms laat herkennen. Wij hebben onderzoek verricht naar hoe de huisarts herkent dat een patiënt behoefte heeft aan palliatieve zorg, terwijl het overlijden nog relatief ver weg kan zijn.

Aan de hand van een 'topiclijst' voerden we semigestructureerde interviews met twintig huisartsen in Nederland (tien mannen en tien vrouwen, gemiddelde leeftijd 48 jaar). Openingsvragen uit de topiclijst waren:

- Kunt u in hoofdlijnen iets vertellen over patiënten die u momenteel palliatieve zorg biedt en over de zorg die u aan hen geeft?

- Hoe heeft u bij deze patiënten de behoefte aan palliatieve zorg herkend? Alle huisartsen gaven schriftelijk toestemming voor deelname aan het onderzoek. De gemiddelde interviewduur was 50 minuten. De huisartsen werkten gemiddeld 38 uur 
per week. Er was een mix van huisartsen werkzaam in een solopraktijk of in een groepspraktijk en ook waren er zowel huisartsen uit stedelijke gebieden als van het platteland vertegenwoordigd. De interviews zijn opgenomen op band, letterlijk uitgetypt en geanonimiseerd.

Daarna werden ze kwalitatief geanalyseerd met ondersteuning van het programma Atlas.ti.

\section{STARTPUNT}

Huisartsen geven aan dat bijvoorbeeld bij mensen met COPD of hartfalen palliatieve zorg soms al jaren voor het overlijden kan starten. Echter, hun eerste associatie gaat toch uit naar zorg in de laatste weken of maanden voor het overlijden, wanneer een patiënt en familie in toenemende mate een beroep op hen doet. Huisartsen identificeren het startpunt van de palliatieve zorg vaak geruime tijd na de diagnose van een levensbedreigende, uiteindelijk dodelijke aandoening. Toch vinden huisartsen de diagnosefase wel een belangrijke fase. Ze bieden ondersteuning aan patiënt en familie, maar het voegt in de beleving van huisartsen weinig toe om dat als het begin van de palliatieve zorg te zien.

Zeker ook omdat bijvoorbeeld bij mensen met kanker een groot deel geheel herstelt. Bij mensen die een chronische ziekte hebben als COPD of hartfalen is genezing niet mogelijk, maar is er kort na de diagnose meestal nog geen sprake van zorgafhankelijkheid.

Spreken over 'een behoefte aan palliatieve zorg' is in de beleving van huisartsen dan weinig zinvol.

\section{PATIËNT EN FAMILIE}

Een combinatie van veelal subtiele signalen zet huisartsen op het spoor van palliatieve zorgbehoeftes: signalen vanuit de patiënt en/of mededelingen van andere zorgprofessionals en naaste familie. Een belangrijk signaal is een afname in zelfredzaamheid: het gaat een patiënt steeds meer moeite kosten om voor zichzelf te zorgen. Dat gaat vaak gepaard met een toenemende bedlegerigheid en meer afhankelijkheid van de zorg van naasten en professionals. De zorgvragen geuit tegen de huisarts worden frequenter en intensiever. Een patiënt die vroeger altijd zelf op het spreekuur kwam, kan dan ineens vragen om een huisbezoek. Het niet meer geheel opknappen na bijkomende aandoeningen, zoals een blaasontsteking, is voor huisartsen ook een signaal dat ze deze patiënten extra in de gaten moeten houden. Ook sociale veranderingen kunnen voor huisartsen een signaal zijn dat een patiënt behoefte heeft aan palliatieve zorg. Bijvoorbeeld als mensen zich terugtrekken, minder gericht zijn op contacten buiten de directe familie en geen plezier meer beleven aan hobby's of activiteiten buiten de deur. Het wordt 'existentiëler', in de zin dat mensen zich gaan richten op de personen en zaken die het meest belangrijk zijn in hun leven, en op afronden en afscheid nemen van het leven.

Huisartsen krijgen vaak ook signalen van de naaste familie. Een partner of andere directe naaste geeft dan aan dat de situatie van de patiënt verslechtert, de zorg heel zwaar wordt en dat hij/zij behoefte heeft om te overleggen.

\section{PROFESSIONALS}

Ook het bericht van de medisch specialist uit het ziekenhuis dat genezing geen optie (meer) is, vormt voor huisartsen een signaal dat een patiënt mogelijk behoefte heeft 
aan palliatieve zorg. Dat is ook het moment dat patiënten door de specialist terugverwezen worden naar hun huisarts en dat de laatste weer hoofdbehandelaar wordt. Daarnaast kan ook de thuiszorg aan de bel trekken. De huisarts wordt dan bijvoorbeeld opgebeld door de wijkverpleegkundige die aangeeft dat het niet goed gaat met de patiënt, dat de familie overbelast is, en dat er iets moet gebeuren. Zo'n signaal in combinatie met andere signalen maakt een huisarts alert en draagt bij aan het besef dat er behoefte is aan palliatieve zorg.

\section{SIGNALEN VAN DE PATIËNT EN ANDEREN DIE DE HUISARTS TRIGGEREN OM PALLIATIEVE ZORG TE STARTEN}

\section{Signalen van de patiënt}

- Veranderingen in zelfredzaamheid en zorgafhankelijkheid

- Niet opknappen van bijkomende aandoeningen

- Sociale veranderingen zoals minder interesse in sociale contacten of hobby's

\section{Signalen van anderen}

- Naaste familie geeft aan dat situatie verslechtert en zorg zwaar wordt

- Mededelingen van andere professionals zoals medisch specialisten en thuiszorg

\section{CONCLUSIES}

Huisartsen spreken niet over 'palliatieve zorg' in de vroege fase van een levensbedreigende ziekte als er (ook) nog curatieve behandelingen worden gegeven of als de patiënt nog niet zorgafhankelijk is.

Subtiele signalen van de patiënt zelf, vaak gecombineerd met mededelingen van andere professionals of van de familie, attenderen huisartsen op een behoefte aan palliatieve zorg. Veel hangt er dus vanaf of die signalen de huisarts al dan niet bereiken.

Uit ander recent onderzoek is bekend dat Nederlandse huisartsen over het algemeen een reactieve houding hebben, ${ }^{3}$ in die zin dat zij ervan uitgaan dat de patiënt zelf moet aangeven welke problemen of zorgvragen hij/zij heeft. Huisartsen willen niet betuttelen of zorg geven waar geen behoefte aan is. Bij patiënten met een levensbedreigende aandoening zou een meer pro-actieve benadering overwogen kunnen worden. Pro-activiteit houdt in dit verband bijvoorbeeld in dat de huisarts al in een vroege fase van de ziekte het initiatief neemt om te communiceren over de zorg die de patiënt en familie wenst als de ziekte voortschrijdt (advance care planning). De term 'palliatieve zorg' hoeft in die communicatie met de patiënt en familie niet te vallen. Het bewustzijn van de huisarts zelf dat palliatieve zorg al kan beginnen als het overlijden nog ver weg, kan er wel toe bijdragen dat dat soort gesprekken over huidige en toekomstige zorgbehoeften tijdig plaatsvinden. Advance care planning kan alleen starten als de patiënt in het vizier van de huisarts is. Uit eerder verricht kwantitatief vragenlijstonderzoek hebben we echter aanwijzingen dat huisartsen soms pas in een laat stadium op de hoogte zijn van de diagnose en prognose, vooral bij patiënten met een andere aandoening dan kanker. ${ }^{4}$ Eén van de verklaringen daarvoor is dat tot in een laat stadium van een ziekte als COPD of hartfalen medisch specialisten de hoofdbehandelaar blijven. Het is aan te bevelen dat medisch specialisten en huisartsen investeren in de uitwisseling van informatie over diagnose en prognose bij mensen die onder behandeling zijn voor progressieve, uiteindelijk fatale aandoeningen. 
Claessen, S., Francke, A., Engels, Y., Deliens, L. Hoe herkennen huisartsen behoefte aan palliatieve zorg? Pallium: 2013, 15(1), 24-25

\section{LITERATUUR}

De literatuurlijst is via mail opvraagbaar bij mieke.vandalen@bsl.nl. 